\title{
Performance, body composition, and physiological response of tambaqui fed diet with green tea extract
}

\author{
Carline Barroso Corrêa(1), Galileu Crovatto Veras(1), Giselle Paula Silva da Silva(1), \\ Marcos Ferreira Brabo ${ }^{(1)}$ and Evaldo Martins Silva ${ }^{(1)}$
}

\begin{abstract}
(1)Universidade Federal do Pará, Instituto de Estudos Costeiros, Faculdade de Engenharia de Pesca, Alameda Leandro Ribeiro, s/no, Aldeia, CEP 68600-000 Bragança, PA, Brazil. E-mail: carlinebarroso@hotmail.com, galileu@ufpa.br, gisellepssilva@gmail.com, mbrabo@ufpa.br, evaldms@ufpa.br
\end{abstract}

\begin{abstract}
The objective of this work was to evaluate the performance, body composition, and physiological state of tambaqui (Colossoma macropomum) fingerlings fed diets containing different levels of green tea (Camellia sinensis) extract (GTE). A completely randomized design was used with five treatments, different levels of GTE $\left(0.00,0.05,0.30,0.55\right.$, and $\left.0.80 \mathrm{~g} \mathrm{~kg}^{-1}\right)$ and three replicates. The diets were offered to fingerlings twice a day, for 90 days. The increase of dietary GTE levels promoted a positive quadratic effect on body lipids, hepatic lipids, retention of body lipids, glucose, and total triglycerides, and the minimum values of these variables were estimated with $0.61,0.54,0.73,0.60$, and $0.30 \mathrm{~g} \mathrm{~kg}^{-1}$ GTE in the diet, respectively. There was a negative quadratic effect of the extract on body protein and hemoglobin with the increased GTE dietary level, and the maximum values of these variables were estimated with 0.59 and $0.46 \mathrm{~g} \mathrm{~kg}^{-1}$ GTE dietary level, respectively. Total cholesterol levels showed a linear reduction with increased GTE dietary level. The inclusion of GTE in the diet, although not affecting performance, decreases body and hepatic fat; reduces the levels of total cholesterol, triglycerides, and glucose; and promotes the increase of body protein of tambaqui fingerlings, improving fish health conditions, during cultivation, and the quality of the final product.

Index terms: Camellia sinensis, Colossoma macropomum, flavonoids, lipid reduction, phytotherapy, plant extracts.

\section{Desempenho, composição corporal e respostas fisiológicas de tambaqui alimentados com dietas com extrato de chá-verde}

Resumo - O objetivo deste trabalho foi avaliar o desempenho, a composição corporal e o estado fisiológico de alevinos de tambaqui (Colossoma macropomum), alimentados com dietas com diferentes teores de extrato de chá-verde (Camellia sinensis, ECV). Utilizou-se um delineamento inteiramente casualizado, com cinco tratamentos, diferentes níveis de ECV $\left(0,00,0,05,0,30,0,55\right.$ e $\left.0,80 \mathrm{~g} \mathrm{~kg}^{-1}\right)$ e três repetições. As dietas foram oferecidas aos alevinos duas vezes ao dia, por 90 dias. O aumento dos níveis de ECV na dieta promoveu um efeito quadrático positivo sobre lipídeo corporal, lipídeo hepático, retenção de lipídeo corporal, glicose e triglicerídeos totais, e os valores mínimos destas variáveis foram estimados com níveis de $0,61,0,54,0,73$, 0,60 e $0,30 \mathrm{~g} \mathrm{~kg}^{-1} \mathrm{ECV}$ na dieta, respectivamente. Houve efeito quadrático negativo sobre proteína corporal e hemoglobina, com o aumento dos níveis de ECV na dieta, e os valores máximos destas variáveis foram estimados com níveis de 0,59 e $0,46 \mathrm{~g} \mathrm{~kg}^{-1} \mathrm{ECV}$ na dieta, respectivamente. Houve redução linear dos níveis de colesterol total, com o aumento dos níveis de inclusão do ECV na dieta. A inclusão de ECV na dieta, apesar de não influenciar o desempenho, reduz a gordura corporal e a do fígado; diminui o colesterol total, os triglicerídeos e a glicose; e promove o aumento da proteína corporal de alevinos de tambaqui, o que melhora a condição de saúde deste peixe, durante o cultivo, e a qualidade do produto final.
\end{abstract}

Termos para indexação: Camellia sinensis, Colossoma macropomum, flavonoides, redução de lipídeos, fitoterapia, extrato de planta.

\section{Introduction}

Even though most antibiotics are not regulated for use in the cultivation of aquatic organisms, the use of these drugs is still a prophylactic practice found in cultivation systems (Figueiredo et al., 2008). As a consequence, the intermittent use of this practice can select bacteria which are resistant to these drugs, and inhibit, or kill beneficial bacteria of the digestive tract (Abdel-Tawwab et al., 2010). However, restrictions to
Pesq. agropec. bras., Brasília, v.53, n.5, p.540-546, May 2018 DOI: 10.1590/S0100-204X2018000500002
This is an open-access article distributed under the Creative Commons Attribution 4.0 International License 
the use of antimicrobials both in the therapeutic form and as growth promoter in animals for food production have been increasing (Figueiredo et al., 2008). Therefore, in the production of aquatic organisms, a possible alternative to antibiotics would be the use of natural products such as herbal medicines. Usually, these herbals have low toxicity, lower side effects, and better biodegradability than antibiotics, which would make them safer for animals and the environment (Ferreira et al., 2017). Herbal medicines have been frequently used in the feed of terrestrial animals, with very satisfactory results, and their use in aquaculture is growing each day (Abdel-Tawwab et al., 2010). The few existing studies on aquaculture have shown the beneficial effects of natural products on immune systems, growth, feed efficiency, and body composition (Santos et al., 2009). These beneficial effects are due to bioactive ingredients such as alkaloids, flavonoids, terpenoids, and steroids (Santos et al., 2009; Uczay et al., 2014).

Among the various known herbal products, green tea (Camellia sinensis) is of particular interest. Studies have shown that green tea can be a useful supplement in fish diets for improving immune systems, survival rates, and antioxidant capacities (Cho et al., 2007; Abdel-Tawwab et al., 2010; Hwang et al., 2013; Nootash et al., 2013; Zhang et al., 2015). This herb can also reduce cholesterol (Cho et al., 2007) and triglycerides in the blood (Abdel-Tawwab et al., 2010). In addition, some authors have reported the ability of green tea to promote growth, by increasing the feed efficiency and reducing the content of fish body lipids (AbdelTawwab et al., 2010; Nootash et al., 2013).

Tambaqui (Colossoma macropomum) is the main native fish species among the major ones grown in Brazil, and it is widely accepted in consumer markets in the North, Midwest and Northeast of the country (Boscolo et al., 2011). The increased cultivation of this species has been attributed to the ease of acquiring juveniles, and to this fish high productivity, high-feed conversion rate, and good growth potential (Gomes et al., 2010). However, despite being widely appreciated, this species shows high-lipid concentrations, which can negatively influence the quality of the final product (Fernandes et al., 2012).

The objective of this work was to evaluate the performance, body composition, and physiological state of tambaqui fingerlings fed diets with the inclusion of different levels of green tea extract.

\section{Materials and Methods}

This project was initially registered in the Comissão de Ética na Pesquisa com Animais de Experimentação (Cepae) of Universidade Federal do Pará, under the protocol number 207-14. A total of 1.000 tambaqui (Colossoma macropomum) fingerlings were purchased from a commercial fish farm located in the municipality of Castanhal, in the state of Pará, Brazil. Fish were transported to the laboratory of pisciculture, at the Faculdade de Engenharia de Pesca, Universidade Federal do Pará, in the municiapality of Bragança, PA, Brazil, where they were stored for 15 days in a $5.000 \mathrm{~L}$ tank, for quarantine and acclimatization. After this period, 300 tambaqui fingerlings were selected, weighed $(4.06 \pm 0.03 \mathrm{~g})$, measured for total length $(4.79 \pm 0.01 \mathrm{~cm})$, and homogeneously and randomly distributed in 15 fiberglass boxes with $300 \mathrm{~L}$ volume in a water-recirculation system, with a stocking density of one fish for each $15 \mathrm{~L}$ water, or 20 fish per box. After 15 days, a completely randomized design experiment was conducted with five treatments, with different levels of green tea extract in the diet $(0.00,0.05,0.30$, 0.55 , and $0.80 \mathrm{~g} \mathrm{~kg}^{-1}$ ), and three replicates, with a 300 $\mathrm{L}$ box as the experimental unit.

The extraction of green tea was carried out according to a methodology adapted from Silva et al. (2007). One kilogram of dried and ground green tea leaves was homogenized in $10 \mathrm{~L}$ of ethanol-water solution $(87 \%)$, and placed in an oven at $58^{\circ} \mathrm{C}$ for $45 \mathrm{~min}$. The obtained extract was filtered using a Whatman \#1 filter under vacuum, to separate the fiber sheets. The filtered solution was subsequently treated with a vacuum rotary evaporator Marconi MA 120/TH (Marconi Equipamentos para Laboratórios Ltda., Piracicaba, SP, Brazil), at $52^{\circ} \mathrm{C}$, for ethanol separation. The remaining solution was filtered again to remove chlorophyll. The extract was then frozen and lyophilized for 24 hours, to remove moisture and obtain a freeze-dried dehydrated extract. The total polyphenol content of this extract, measured using the Folin-Ciocalteu method (Singleton \& Rossi, 1965), was $268.46 \mathrm{mg} \mathrm{g}^{-1}$. The lyophilized green tea extract was then stored at $-20^{\circ} \mathrm{C}$, until preparation of the experimental diets. 
Five isoproteic ( $40 \%$ crude protein) and isocaloric $\left(3,300 \mathrm{kcal} \mathrm{DE} \mathrm{kg}^{-1}\right)$ diets were formulated and prepared to meet the nutritional requirements of the species during the development stage (Table 1). For each concentration, the green tea extract was weighed and diluted in $100 \mathrm{~mL}$ water heated to $50^{\circ} \mathrm{C}$, and then mixed with the other ingredients to achieve $0.00,0.05$, $0.30,0.55$, and $0.80 \mathrm{~g} \mathrm{~kg}^{-1}$ final concentrations. After the homogenization of the ingredients and of the green tea extract, the diets were pelleted in an electric grinder, and dried in a forced-ventilation oven at $50^{\circ} \mathrm{C}$ for 24 hours. They were subsequently crushed and sieved to obtain pellets compatible with the development stage of the species.

The feed was supplied twice a day (at 8:00 and 16:00 h), until apparent satiety, for 90 days. Each day, one hour after the last feeding, the boxes were siphoned to remove faeces and any remaining feed. Biometric measurements were performed every 15 days, in order to track the growth of the fingerlings, and to make corrections in the supply of rations.

The physicochemical parameters of the water, such as temperature $\left(29.59 \pm 0.10^{\circ} \mathrm{C}\right)$, dissolved oxygen

Table 1. Amount and chemical composition of the experimental diet ingredients of tambaqui, Colossoma macropomum, fingerlings.

\begin{tabular}{lr}
\hline Ingredient & Amount $\left(\mathrm{g} \mathrm{kg}^{-1}\right)$ \\
\hline Soybean meal & 645.00 \\
Fish meal & 100.00 \\
Meat meal & 50.00 \\
Corn meal & 45.50 \\
Wheat bran & 100.00 \\
Soybean oil & 45.50 \\
Dicalcium phosphate & 6.50 \\
Tocopheryl acetate $(1)$ & 1.00 \\
Premix vit./min ${ }^{(2)}$ & 5.00 \\
DL - methionine & 1.60 \\
\hline Total & $1,000.00$ \\
\hline Chemical composition & 400.00 \\
Crude protein $\left(\mathrm{g} \mathrm{kg}^{-1}\right)$ & $3,300.00$ \\
Digestible energy $\left(\mathrm{kcal} \mathrm{kg}^{-1}\right)$ & 75 \\
Ether extract $\left(\mathrm{g} \mathrm{kg}^{-1}\right)$ & 50.00 \\
Crude fibre $\left(\mathrm{g} \mathrm{kg}^{-1}\right)$ & \\
\hline
\end{tabular}

(1)Tocopherol acetate: $50 \%$ activity. ${ }^{(2)}$ Vitamin and mineral premixes at warranty levels per kilogram of product: vitamin A, 24,000 IU; vitamin D3, 6,000 IU; vitamin E, $300 \mathrm{mg}$; vitamin K3, $30 \mathrm{mg}$; vitamin B1, $40 \mathrm{mg}$; vitamin B2, $40 \mathrm{mg}$; vitamin B6, $35 \mathrm{mg}$; vitamin B12, $80 \mathrm{mg}$; folic acid, 12 $\mathrm{mg}$; Ca pantothenate, $100 \mathrm{mg}$; vitamin C, $600 \mathrm{mg}$; biotin, $2 \mathrm{mg}$; choline, 1,000 mg; niacin; Fe, 200 mg; Cu, 35 mg; Mn, 100 mg; Zn, 240 mg; I, 1.6 $\mathrm{mg}$; Co, $0.8 \mathrm{mg}$.
(6.01 $\left.\pm 0.2 \mathrm{mg} \mathrm{L}^{-1}\right)$ and $\mathrm{pH}(5.95 \pm 0.30)$, were measured daily. An oximeter DO-5510 (Lutron, Taipei, Taiwan) was used to monitor the temperature and dissolved oxygen, and a benchtop multiparameter metre Hanna HI3512 (Hanna Instruments, Woonsocket, Rhode Island, USA) was used to monitor the $\mathrm{pH}$ level. Ammonia levels $\left(0.002 \pm 0.001 \mathrm{mg} \mathrm{L}^{-1}\right)$ were measured weekly with a Labcon Test Kit (Indústria e Comércio de Alimentos Desidratados Alcon Ltda., Balneário de Camboriú, SC, Brazil).

After the end of the experiment, fish were fasted for a period of 24 hours. They were, then, counted, measured and weighed, to determine the following performance indicators: survival rate, SR $(\%)=[($ final number of fish / initial number of fish) $\times 100$ ]; weight gain, WG $(\mathrm{g})=$ (final weight - initial weight $)$; length gain, LG $(\mathrm{cm})=$ (final length - initial length); specific growth rate, $S G R(\%$ per day $)=[(\ln$ final length $-\ln$ initial length) / (experimental period) $\times 100$ ]; daily feed intake, DFI (g per day) = feed intake / experimental period; feed conversion, $\mathrm{FC}=$ feed intake / weight gain; and protein efficiency ratio, $P E R=$ weight gain / protein intake.

After the last biometric measurement, fish were individually euthanized with thermal shock in ice water. They were then gutted, with the liver, viscera, and carcass, separated and individually weighed to obtain the hepatosomatic index HSI $(\%)=[($ liver weight / final weight of fish) $\mathrm{x} 100$ ]; viscerosomatic index, VSI $(\%)=[($ weight of viscera $/$ final weight of fish $) \times 100]$; and carcass yield, CY $(\%)=[($ weight of gutted fish / final weight of fish) $\times 100$ ]

Before applying the treatments, 10 fingerlings were killed with thermal shock in ice water, stored in a freezer at $-20^{\circ} \mathrm{C}$, and gutted for further analysis of body composition. The same procedure was followed at the end of the experiment, with 120 fish (24 individual fish per treatment, that is, eight fish per replicate).

For the analysis of body composition, samples were lyophilized and individually crushed in a knife mill. After homogenization, the following parameters were determined in triplicate, according to the methodology of the AOAC (Horwitz, 2000): moisture, crude protein, and total and liver lipids.

Crude protein retention was determined as follows: $\mathrm{CPR}(\%)=\{[($ final protein $\times$ final weight $)-($ initial protein $\times$ initial weight)] / final weight $\} \times 100$; and lipid retention, LR (lipid retention) $(\%)=\{[($ final lipid 
$\times$ final weight $)-($ initial lipid $\times$ initial weight)] / final weight $\} \times 100$.

After the last biometric measurement, blood samples from five fish from each experimental unit were extracted by puncturing the caudal vessels with needles and $1 \mathrm{~mL}$ syringes previously wetted in $10 \%$ EDTA. Each blood sample of each fish was stored in a $1.5 \mathrm{~mL}$ microcentrifuge tube for subsequent analysis. The glycemia rate $\left(\mathrm{mg} \mathrm{dL}^{-1}\right)$ was measured in $10 \mu \mathrm{L}$ blood with an automatic metre Accu-Chek Active (Roche, São Paulo, SP, Brazil). The hematocrit was determined with the microhematocrit method, in percentage, after blood centrifugation at 20,379 $g$ for 5 min (Ranzani-Paiva et al., 2013). The total plasma protein obtained after centrifugation $\left(\mathrm{g} \mathrm{dL}^{-1}\right)$ was determined with a refractometer Quimis Q767-5 (Quimis Aparelhos Científicos, Diadema, SP, Brazil). The total hemoglobin concentration $\left(\mathrm{g} \mathrm{dL}^{-1}\right)$ was determined at $540 \mathrm{~nm}$ with the cyanmethemoglobin method using spectrophotometry Biospectro SP22 (Labmais Ltda., Curitiba, PR, Brazil) (Ranzani-Paiva et al., 2013). The count of total erythrocytes was determined in a Neubauer chamber.

The Statistica software, version 10.1 (Statsoft, Tulsa, OK, USA) was used to perform the statistical analysis. The data for each variable were tested for normality (Shapiro-Wilk W-test), and for homoscedasticity (Levène's test). An analysis of variance was then performed, and when significant at $5 \%$ probability, a linear or quadratic (second order) regression analysis was adjusted. To choose the most suitable regression model, the significance of the regression coefficients, the magnitude of the coefficients of determination, and the biological response of each variable were considered.

\section{Results and Discussion}

There was no significant influence of diets with different levels of green tea extract on the following parameters: survival rate $(99.67 \pm 0.75 \%)$; final weight $(32.93 \pm 3.03 \mathrm{~g})$ and length $(9.73 \pm 0.36 \mathrm{~cm})$; weight $(28.87 \pm 3.03 \mathrm{~g})$ and length $(4.94 \pm 0.37 \mathrm{~cm})$ gain; specific growth rate $(2.31 \pm 0.10 \%$ per day); daily feed intake $(37.06 \pm 2.39 \mathrm{~g})$; feed conversion $(1.31 \pm 0.05)$; and protein efficiency ratio (1.91 \pm 0.09$)$ of tambaqui fingerlings.

The results describing the performance of tambaqui fingerlings fed different green tea extract concentrations differ from those of studies on Paralichthys olivaceus (Cho et al., 2007) and Oreochromis niloticus (AbdelTawwab et al., 2010), in which the growth variables were higher in diets containing the phytotherapeutic green tea. However, Hwang et al. (2013) observed greater growth in Sebastes schlegeli, when fish fed control diets. In a study on rainbow trout, Oncorhynchus mykiss, the inclusion of green tea in the diet did not influence the growth of this species (Nootash et al., 2013), concurring with the results obtained in the present study on tambaqui fingerlings. Thus, supplementation of green tea extract in fish diets may result in different forms of action in the metabolism of these animals, depending on how green tea is supplemented in the diet (extract, leaves, or by-products), the concentrations used, the time of delivery, and the development stage of fish, as well as the species studied.

There was no significant influence of diets with green tea extract on the hepatosomatic $(1.84 \pm 0.15 \%)$ and viscerosomatic $(6.90 \pm 0.20 \%)$ indices, and on carcass yield $(91.00 \pm 1.5 \%)$ of tambaqui fingerlings.

Viscerosomatic and hepatosomatic indices, and carcass yields are directly influenced by the amount of fat in the gut, liver, and fish muscle. High levels of body fat adversely influence the fish quality by reducing the carcass yield, meat quality, and storage time of the final product. However, despite the known reducing effect of fat promoted by this phytotherapeutic herb, the different levels of green tea extract in the tambaqui fingerling diet did not influence these indices, as fingerlings tend to have lower-fat deposition in the viscera and liver.

There was a positive quadratic effect on the body lipid $\left(\mathrm{y}=6.4166 \mathrm{x}^{2}-7.8449 \mathrm{x}+19.765 ; \mathrm{R}^{2}=0.8399\right)$, hepatic lipid $\left(\mathrm{y}=4.2712 \mathrm{x}^{2}-4.6372 \mathrm{x}+3.5245\right.$; $\left.\mathrm{R}^{2}=0.7211\right)$, and retention of body lipid $\left(\mathrm{y}=68.983 \mathrm{x}^{2}\right.$ - 101.34x $\left.+229.48 ; R^{2}=0.8748\right)$, with increasing levels of green tea extract in the diet. The minimum values of these variables were estimated with $0.61,0.54,0.73$ $\mathrm{g} \mathrm{kg}^{-1} \mathrm{ECV}$ dietary level, respectively.

The body lipid results of tambaqui fingerlings corroborate the data obtained from studies on Nile tilapia (Abdel-Tawwab et al., 2010) and Sebastes schlegeli (Hwang et al., 2013), in which fish fed diets containing green tea and the extract of this phytotherapic, respectively. However, juveniles of Paralichthys olivaceus fed diets containing 5\% of 
different sources of green tea showed a decrease only of liver-fat levels, without any influence on body lipid (Cho et al., 2007). Likewise, Vera-Cruz et al. (2010), in a study on Wistar-Hannover rats, showed that diet containing $1 \mathrm{~g}$ green tea had a significant influence on the decrease of liver lipid.

The reduction of fat happens because green tea increases the metabolic rate and the use of fatty acids in the muscle tissue (Murase et al., 2006) and liver (Ota et al., 2005), increasing the catabolism of fat in these tissues by oxidation (Murase et al., 2006). Thus, the lower levels of body and liver lipids found in tambaqui fingerlings fed diets with green tea extract were caused by the flavonoids, primarily from the catechin family, and caffeine present in green tea, which stimulate the thermogenesis and oxidation of body fat (Vera-Cruz et al., 2010).

Fat reduction provided by the inclusion of green tea extract in the diet is important because it can bring important benefits to the cultivation of tambaqui, since this species normally shows great lipid concentrations. Excess fat can negatively influence the final quality of the product, as a consequence of postmortem degradative changes occurring faster due to oxidative reactions during storage (Fernandes et al., 2012). In this way, obtaining fish with less fat, in addition to offering a healthier product, is expected to increase its shelf life expectancy.

Green tea extract included in the diet significantly influenced the body protein levels in tambaqui fingerlings, and the increased levels of the extract showed a negative quadratic effect $\left(\mathrm{y}=-7.9121 \mathrm{x}^{2}+9.2657 \mathrm{x}+62.991 ; \mathrm{R}^{2}=0.5837\right)$. The maximum values of these variables were estimated with $0.59 \mathrm{~g} \mathrm{~kg}^{-1}$ GTE dietary level.

As in the present study on tambaqui, the inclusion of green tea in the diet increased the body protein of Nile tilapia fingerlings (Abdel-Tawwab et al., 2010). In a study on juveniles of Sebastes schlegeli, the inclusion of herbal medicine increased both body and liver proteins (Hwang et al., 2013). However, green tea in the diets of Paralichthys olivaceus resulted in the increase of hepatic proteins and did not alter the amount of body proteins.

The increase of protein levels in the body composition of fingerlings fed diets containing herbal medicine is related to substances such as flavonoids, which once absorbed, influence many biological functions such as protein synthesis (Nootash et al., 2013). Insulin, in addition to acting on glucose homeostasis, regulates protein synthesis and fat stocks by stimulating the absorption of flavonoids (Hasegawa et al., 2003). Flavonoids of the catechin family and condensed tannins have strong affinities for proteins, and they can join different amino acid residues, thus interfering with their digestion and absorption (Cooper et al., 2005). Moreover, the inclusion of green tea in a fish diet can increase digestibility, leading to an improvement in the use and deposition of nutrients (Abdel-Tawwab et al., 2010), including proteins.

Levels of inclusion of green tea extract in the diet did not influence the total blood protein of tambaqui fingerlings. However, distinct results have been reported in studies on P. olivaceus (Cho et al., 2007), Nile tilapia (Abdel-Tawwab et al., 2010), and rainbow trout (Nootash et al., 2013), with these species showing higher total protein values when fed diets containing green tea. According to Nootash et al. (2013), the high-plasma protein levels provided by green tea can also be associated with an increased synthesis of active proteins, which results in a strong response of the innate immune system.

A significant influence on blood glucose was observed with the inclusion levels of green tea extract in the tambaqui fingerling diets. A positive quadratic effect was observed $\left(y=73.003 x^{2}-86.975 x+84.74\right.$; $\left.\mathrm{R}^{2}=0.8207\right)$ on blood glucose of fingerlings, with the increasing levels of green tea extract in the diet. The maximum values of these variables were estimated with $0.60 \mathrm{~g} \mathrm{~kg}^{-1}$ GTE dietary level.

According to $\mathrm{Wu}$ et al. (2004), one of the effects of green tea is the reduction of blood glucose levels in animals and humans; this herb acts as a promoter of glucose metabolism and insulin action. This effect is possibly due to the action of flavonoids, which, when absorbed, stimulate insulin to act on glucose homeostasis (Hasegawa et al., 2003). This activity may explain why the glucose levels of tambaqui fingerlings of the present study were lower when green tea extract was added to the diet. Conversely, studies on Nile tilapia (Abdel-Tawwab et al., 2010) and Sebastes schlegeli (Hwang et al., 2013) showed higher-mean values of glucose, when green tea was present in the diet.

The dietary level of green tea extract also exerted a significant influence on the hemoglobin of the 
tambaqui fingerlings. The increased levels of green tea extract in the diet led to a negative quadratic effect $\left(y=-11.112 x^{2}+10.159 x+8.3584 ; R^{2}=0.7653\right)$ on the hemoglobin levels of fish. The minimum value of this variable was estimated with $0.46 \mathrm{~g} \mathrm{~kg}^{-1} \mathrm{ECV}$ dietary level. The hematocrit and erythrocyte numbers of tambaqui fingerlings were not significantly affected in fish fed diets with the inclusion of green tea extract.

The increase of the average hemoglobin level of tambaqui fingerlings fed diets with green tea extract can be attributed to the presence of caffeine as one of its components. Caffeine increases the heart rhythm (Chacko et al., 2010), which leads to a faster circulation of blood to the tissues. This increase promotes the recruitment of erythrocytes, augmenting the amount of hemoglobin. However, despite the increase of hemoglobin, the hematocrit and erythrocyte values for the tambaqui fingerlings remained unchanged throughout the experiments. Additionally, the hemoglobin and hematocrit values observed in the present study contradicted those of Hwang et al. (2013), whose values were higher in the control treatment, and lower in treatments with higher amounts of green tea extract in the diet. In studies on Nile tilapia, diets with higher-green tea levels showed an elevated value of erythrocytes (Abdel-Tawwab et al., 2010), although hematocrit and hemoglobin variables were not evaluated. Thus, due to lack of information and conflicting results in the existing literature, more studies are needed to clarify the effect of green tea on these variables.

Green tea extract levels significantly affected the total cholesterol and triglyceride levels of the tambaqui fingerlings. There was a linear decreasing effect of total cholesterol $\left(\mathrm{y}=-341.26 \mathrm{x}+315.36 ; \mathrm{R}^{2}=0.8755\right)$ and a positive quadratic total triglyceride levels $\left(y=226.55 x^{2}-135.61 x+117.22 ; R^{2}=0.7618\right)$, with the increasing levels of green tea extract in the diet. The minimum value of total triglyceride was estimated with $0.30 \mathrm{~g} \mathrm{~kg}^{-1} \mathrm{ECV}$ in the diet.

The significant effect of the reduction of total cholesterol levels of tambaqui fingerlings corroborates data obtained from a study of black rockfish, Sebastes schlegeli, by Hwang et al. (2013). Juvenile Paralichthys olivaceus fed diets containing 5\% of different sources of green tea (fresh leaf, dried leaf, commercial product, and green tea extract) showed a reduction of the low-density lipoprotein cholesterol (LDL) levels (Cho et al., 2007).
The catechins may reduce food intake, lipid absorption, cholesterol, and blood triglycerides, which can contribute to weight loss and improved lipid profile (Saigg \& Silva, 2009) because they regulate various enzymes that actively participate in the anabolism and catabolism processes of adipose tissue lipids (Zhong et al., 2006). Camellia sinensis intake also reduces the levels of the hormone leptin in the blood, thus favouring the reduction of fat absorption (Duarte et al., 2014). Moreover, this herbal medicine assists in maintaining appropriate levels of cholesterol by a number of mechanisms, including inhibiting the absorption of cholesterol and the reabsorption of bile acids, regulating the synthesis of cholesterol between liver and intestine (Chen et al., 2008).

\section{Conclusions}

1. The performance of tambaqui fingerlings is not influenced by the inclusion of green tea extract in the diet.

2. Tambaqui fingerlings fed green tea extract in diet show reduced body fat levels, as well as increased protein levels, which improves the quality of the final product.

3. The inclusion of green tea extract in the diet improves the health conditions of tambaqui, besides decreasing the hepatic fat, total cholesterol, triglycerides, and glucose levels of this fish.

\section{Acknowledgments}

To Fundação Amazônia de Amparo a Estudos e Pesquisa do Pará (Fapespa), for the scholarship granted and for financial support.

\section{References}

ABDEL-TAWWAB, M.; AHMAD, M.H.; SEDEN, M.E.A.; SAKR, S.F. Use of green tea, Camellia sinensis, L., in practical diet for growth and protection of Nile tilapia, Oreochromis niloticus (L.), against Aeromonas hydrophila infection. Journal of the World Aquaculture Society, v.41, p.203-213, 2010. DOI: 10.1111/j.1749-7345.2010.00360.x.

BOSCOLO, W.R.; SIGNOR, A.; FREITAS, J.M.A.; BITTENCOURT, F.; FEIDEN, A. Nutrição de peixes nativos. Revista Brasileira de Zootecnia, v.40, p.145-154, 2011.

CHACKO, S.M.; THAMBI, P.T.; KUTTAN, R.; NISHIGAKI, I. Beneficial effects of green tea: a literature review. Chinese Medicine, v.5, art.13, 2010. DOI: 10.1186/1749-8546-5-13. 
CHEN, Z.-Y.; JIAO, R.; MA, K.Y. Cholesterol-lowering nutraceuticals and functional foods. Journal of Agricultural and Food Chemistry, v.56, p.8761-8773, 2008. DOI: 10.1021/ jf $801566 r$.

CHO, S.H.; LEE, S.-M.; PARK, B.H.; JI, S.-C.; LEE, J.; BAE, J.; $\mathrm{OH}, \mathrm{S} .-\mathrm{Y}$. Effect of dietary inclusion of various sources of green tea on growth, body composition and blood chemistry of the juvenile olive flounder, Paralichthys olivaceus. Fish Physiology and Biochemistry, v.33, p.49-57, 2007. DOI: 10.1007/s10695-0069116-3.

COOPER, R.; MORRÉ, D.J.; MORRÉ, D.M. Medicinal benefits of green tea: part I. Review of noncancer health benefits. Journal of Alternative and Complementary Medicine, v.11, p.521-528, 2005. DOI: $10.1089 / \mathrm{acm} .2005 .11 .521$.

DUARTE, J.L.G.; PRETTO, A.D.B.; NÖRNBERG, F.R.; CONTER, L.F. A relação entre o consumo de chá verde e a obesidade: Revisão. Revista Brasileira de Obesidade, Nutrição e Emagrecimento, v.8, p.31-39, 2014.

FERNANDES, A.C; MEDEIROS, C.O.; BERNARDO, G.L.; EBONE, M.V.; DI PIETRO, P.F.; ASSIS, M.A.A. de; VASCONCELOS, F. de A.G. de. Benefits and risks of fish consumption for the human health. Revista de Nutrição, v.25, p. 283-295, 2012. DOI: 10.1590/S1415-52732012000200010.

FERREIRA, P. de M.F.; ROCHA, J.S.; GOMES, J.R.; CALDAS, D.W.; MARTINS, M.T.S.; OLIVEIRA, J.M. de; SALARO, A.L.; ZUANON, J.A.S. Curcuma longa suplementation in the diet of Astyanax aff. bimaculatus in preparation for transport. Aquaculture Research, v.48, p.4524-4532, 2017. DOI: 10.1111/ are.13277.

FIGUEIREDO, H.C.P.; GODOY, D.T. de; LEAL, C.A.G. Antibióticos na aqüicultura. Panorama da Aqüicultura, v.18, p.42-49, 2008.

GOMES, L.C.; SIMÕES, L.N.; ARAÚJO-LIMA, C.A.R.M. Tambaqui (Colossoma macropomum). In: BALDISSEROTTO, B.; GOMES, L. de C. (Org.). Espécies nativas para piscicultura no Brasil. 2.ed. Santa Maria: Ed. da UFSM, 2010. p.175-204.

HASEGAWA, N.; YAMADA, N.; MORI, M. Powdered green tea has antilipogenic effect on Zucker rats fed a high-fat diet. Phytotherapy Research, v.17, p.477-480, 2003. DOI : 10.1002/ptr.1177.

HORWITZ, W. (Ed.). Official methods of analysis of AOAC international. $17^{\text {th }}$ ed. Arlington: Association of Official Analytical Chemists, 2000.

HWANG, J.-H.; LEE, S.-W.; RHA, S.-J.; YOON, H.-S.; PARK, E.-S.; HAN, K.-H.; KIM, S.-J. Dietary green tea extract improves growth performance, body composition, and stress recovery in the juvenile black rockfish, Sebastes schlegeli. Aquaculture International, v.21, p.525-538, 2013. DOI: 10.1007/s10499-0129586-5.

MURASE, T.; HARAMIZU, S.; SHIMOTOYODOME, A.; TOKIMITSU, I.; HASE, T. Green tea extract improves running endurance in mice by stimulating lipid utilization during exercise. American Journal of Physiology. Regulatory, Integrative and
Comparative Physiology, v.290, p.R1550-R1556, 2006. DOI: 10.1152/ajpregu.00752.2005.

NOOTASH, S.; SHEIKHZADEH, N.; BARADARAN, B.; OUSHANI, A.K.; MOGHADAM, M.R.M.; NOFOUZI, K.; MONFAREDAN, A.; AGHEBATI,L.;ZARE, F.; SHABANZADEH, $\mathrm{S}$. Green tea (Camellia sinensis) administration induces expression of immune relevant genes and biochemical parameters in rainbow trout (Oncorhynchus mykiss). Fish and Shellfish Immunology, v.35, p.1916-1923, 2013. DOI: 10.1016/j.fsi.2013.09.030.

OTA, N.; SOGA, S.; SHIMOTOYODOME, A.; HARAMIZU, S.; INABA, M.; MURASE T.; TOKIMITSU, I. Effects of combination of regular exercise and tea catechins intake on energy expenditure in humans. Journal of Health Sciences, v.51, p.233-236, 2005. DOI: $10.1248 /$ jhs. 51.233 .

RANZANI-PAIVA, M.J.T.; PÁDUA, S.B. de; TAVARES-DIAS, M.; EGAMI, M.I. Métodos para análise hematológica em peixes. Maringá: Eduem, 2013. 144p.

SAIGG, N.L.; SILVA, M.C. Efeitos da utilização do chá verde na saúde humana. Universitas: Ciências da Saúde, v.7, p.69-89, 2009. DOI: $10.5102 /$ ucs.v7i1.882.

SANTOS, E.L.; LUDKE, M.C.M.M.; LIMA, M.R. Extratos vegetais como aditivos em rações para peixes. Revista Eletrônica Nutritime, v.6, p.789-800, 2009.

SILVA, E.M.; ROGEZ, H.; LARONDELLE, Y. Optimization of extraction of phenolics from Inga edulis leaves using response surface methodology. Separation and Purification Technology, v.55, p.381-387, 2007. DOI: 10.1016/j.seppur.2007.01.008.

SINGLETON, V.L.; ROSSI, J.A. Colorimetry of total phenolics with phosphomolybdic-phosphotungstic acid reagents. American Journal of Enology and Viticulture, v.16, p.144-158, 1965.

UCZAY, J.; PIANESSO, D.; ADORIAN, T.J.; MOMBACH, P.I.; COLDEBELLA, I.J.; LAZZARI R. Própolis em dietas para o jundiá (Teleostei, Pimelodidae). Bioscience Journal, v.30, p.19121918, 2014.

VERA-CRUZ, M.; NUNES, E.; MENDONÇA, L.; CHAVES, É; FERNANDES, M.L. de L.A. Efeito do chá verde (Camelia sinensis) em ratos com obesidade induzida por dieta hipercalórica. Jornal Brasileiro de Patologia e Medicina Laboratorial, v.46, p.407-413, 2010. DOI: 10.1590/S1676-24442010000500010.

WU, L.-Y.; JUAN, C.-C.; HO, L.-T.; HSU, Y.-P.; HWANG, L.S. Effect of green tea supplementation on insulin sensitivity in Sprague-Dawley rats. Journal of Agricultural and Food Chemistry, v.52, p.643-648, 2004. DOI: 10.1021/jf030365d.

ZHANG, Y.; ZHOU, Y.; SANG, B.; WAN, X.; YANG, Y.; ZHANG, J.; WELKER, T.L.; LIU, K. Effect of dietary Chinese tea on growth performance, disease resistance and muscle fatty acid profile of channel catfish (Ictalurus punctatus). Aquaculture International, v.23, p.683-698, 2015. DOI: 10.1007/s10499-014-9846-7.

ZHONG, L.; FURNE, J.K.; LEVITT, M.D. An extract of black, green, and mulberry teas causes malabsorption of carbohydrate but not of triacylglycerol in healthy volunteers. The American Journal of Clinical Nutrition, v.84, p.551-555, 2006. DOI: 10.1093/ajen/84.3.551. 